\title{
О.Д. Крушельницький, І.В. Огороднійчук \\ БІОЛОГІЧНІ ЗАГРОЗИ ТА ЇХ ВПЛИВ НА ЕПІДЕМІЧНУ СИТУАЦІЮ У ЗБРОЙНИХ СИЛАХ УКРАЇНИ
}

\author{
Українська військово-медична академія, м. Київ
}

\begin{abstract}
Мета роботи - на основі аналізу літературних джерел виявити вплив біологічних загроз на епідемічну ситуацію у збройних Силах України та проаналізувати управління ризиками виникнення інфекційних захворювань.
\end{abstract}

Ключові слова: біологічні загрози, епідемічна ситуація, екологічна безпека, біологічні агенти.

Одним $з$ питань сьогодення, що найгостріше стоїть перед світовим суспільством і потребує нагального вирішення, є питання біологічної безпеки. Економічно розвинуті країни усвідомили та сорормували загальні засади щодо необхідності збалансованого соціальноекономічного розвитку суспільства та охорони навколишнього природного середовища, раціонального використання природних ресурсів і захисту біологічної безпеки.

Дані про використання патогенних біологічних агентів (ПБА) з метою знищення людей досить численні і сягають стародавніх часів. До середини XIX ст., початку «золотої пори» мікробіології, її застосування спиралося на емпіричні дані. Розповсюдження інсрекційних захворювань, їх небезпека для здоров'я і життя людей, висока уражаюча здатність приваблювали політиків і військовиків до використання збудників в ролі зброї масового ураження.

У світі мали місце непоодинокі випадки терористичних актів з використанням ПБА, тому питання, які пов'язані з поліпшенням біозахисту та біологічної безпеки, є своєчасними та актуальними для України.

Окремо визначається проблема біологічної загрози, пов'язана з біологічним тероризмом і використанням біологічної зброї.

Для дотримання прав людини на біологічну безпеку під час війни необхідна наявність системи заходів біологічного захисту як складової національної безпеки взагалі та забезпечення епідемічного благополуччя зокрема.

Різноманіття біологічних загроз спонукає до створення системи біозахисту і біобезпеки населення та ЗС
України, яка складається з підсистем адекватно напрямкам виникаючих і можливих ризиків. Їх побудова та фрункціонування залежать від системоутворювальних і системокоригувальних чинників. Заходи біозахисту та біобезпеки є підсистемою у системі екологічної безпеки, а та, у свою чергу, є підсистемою в системі національної безпеки України.

Екологічна безпека - це такий стан довкілля, при якому забезпечується запобігання погіршенню екологічної обстановки та виникненню небезпеки для здоров'я людей. Біозахист і біобезпека також орієнтовані на охорону здоров'я громадян. Їх найбільшою складовою на підставі «Концепції державної цільової програми біобезпеки та біозахисту на 2018-2023 роки» можна вважати протиепідемічне забезпечення населення та Збройних Сил України, тому що ії зміст має значну частку епідемічних аспектів. По вертикалі ця підсистема $€$ компонентою інших різновидів державної безпеки.

На нашу думку, доцільно визначити зміст її системоутворювальних і системокоригувальних чинників. До системоутворювальних чинників належать: заклади, установи, обладнання, спеціально підготовлений персонал, а також закони України.

До системокоригувальних чинників належать закони, кодекси та інші нормативно-правові акти, основною метою яких $є$ оперативне забезпечення біозахисту та біобезпеки держави відповідно до змін обстановки. Окремим напрямом в системі заходів протиепідемічного захисту слід виділити протидії біотероризму.

Дезорганізуючий вплив епідемічної ситуації, зумовлений тієї чи іншою інфекцією на можливість використання військ за фрункціональним призначенням, визначає її військово-епідеміологічне значення, яке характеризує рангове положення конкретної нозології. Крім того, аналізуючи епідемічний рівень небезпеки, бажано брати до уваги те, що багато інфекційних хвороб відсутні серед особового складу військ і серед населення України, але вони мають високу потенційну загрозу. Тому, на нашу думку, є необхідність визнати як потенційно високоепідемічно значимі не тільки ті, що реально реєструються, 
а й такі інфекційні хвороби, яких немає на теперішній час.

Питання біобезпеки - це питання управління ризиками. Як будь-яке управління воно має три етапи: інформаційний, аналітичний, організаційний.

При визначенні ризику виникнення захворювання спочатку описують захворюваність (визначають час ризику, групу ризику, територію ризику) з наступним фрормулюванням припущень про чинники ризику.

Реалізація біологічного ризику виникає лише за наявності та взаємодії трьох взаємопов'язаних складових (епідеміологічної тріади в контексті біологічного ризику): джерела біоризику, механізму або способу передачі впливу, реципієнта чи сприйнятливого до впливу об'єкта. За відсутності або вилученні навіть одного з цих елементів, подальший розвиток епідемічних ускладнень неможливий.

На тлі помітних досягнень у дослідженні інфекційних хвороб і боротьби з ними все частіше з'являються нові й повертаються старі інфекції.

Нові, раніше невідомі науці хвороби інорекційного ґенезу, отримали назву емерджентних (від англ. emergency - раптовість, непередбачуваність, незвичність). Згідно з визначенням ВООЗ і МЕБ (Міжнародне епізоотичне бюро), це інфекції, які з'являються вперше у світі або на окремій території, швидко розповсюджуються, загрожуючи здоров'ю людей і тварин. Як правило, щодо них немає ефективних засобів лікування i профрілактики. Вони схильні до неконтрольованого транскордонного поширення. У цій групі на частку зоонозів припадає близько 75 \%, багато з хвороб належать до природно-осередкових інсрекцій [1].

На сьогодні, за даними ВОО3, налічується понад 100 емерджентних інфекцій: тяжкий гострий респіраторний синдром, ВІЛ-інфекція, пташиний грип, обумовлений вірусом A/H5N1 та іншими субтипами цього збудника, пандемічний (калісорнійський) грип, спричинений вірусом A/H1N1/California/04/09, геморагічна гарячка Денге, жовта гарячка, гарячки Західного Нілу, Зіка, Ласса, Марбург і Ебола, хвороба Лайма та інші. Їх список невпинно поповнюється [2].

До реемерджентних інфекцій (від англ. re-emergency - повернення емерджентних хвороб) належать старі, раніше «переможені» та контрольовані інфрекційні захворювання, що знову розповсюдились. Вважається, що боротьба з ними важка або неможлива через їх надто швидке розповсюдження та атиповий перебіг [3].

У наш час до реемерджентних інсрекцій належать кір, дисртерія, кашлюк, малярія, сезонний грип, вітрянка тощо. Фактично будь-яка емерджентна інорекція після тривалого зниження рівня захворюваності з плином часу може стати реемерджентною. Емерджентні та реемер- джентні інфекції визнані сучасною пріоритетною проблемою охорони здоров'я міжнародного значення.

Появі і розповсюдженню емерджентних та реемерджентних інфрекцій можуть сприяти чотири групи фракторів [1-3]:

1. Біологічні - генетичні механізми мінливості збудників, зокрема модифікації, мутації, рекомбінації, дисоціації, плазміди бактерій, неспадкові модифрікації вірусів. У процесі виникнення різних варіантів мікроорганізми набувають нових рис патогенності та стійкості, можуть формувати нові природно-осередкові зони. Така мінливість допомагає збудникові уникати відповіді імунної системи хазяїна, забезпечуючи собі персистенцію в макроорганізмі, підвищувати свою вірулентність і стійкість до антимікробних препаратів.

2. Зоогеограсрічні - почастішання прямих і непрямих контактів людини з тваринним світом, що створює поліпшені умови для пасажів патогенів, підвищення їх вірулентності, виникнення генетичних рекомбінацій. Відбувається інтродукція зоонозного збудника в людську популяцію, а далі - його поширення.

3. Соціально-економічні - зміна щільності населення і рівня його життя. Загальновідомо, що густа заселеність і бідність населення, війни та природні катаклізми сприяють появі нових і розповсюдженню віддавна існуючих інорекцій.

4. Штучно сплановані - навмисне підвищення патогенності відомих мікроорганізмів, їх резистентності до антибіотиків і противірусних препаратів, створення нових збудників інфекційних хвороб, найбільш ефективних їх комбінацій і способів поширення в людській популяції та серед тварин з метою досягнення максимального ураження, що вкладається в сучасне уявлення про біологічну війну і біотерористичну атаку.

Експерти Національного інституту алергії та інорекційних захворювань (NIAID) розділили збудників емерджентних і реемерджентних інфекцій за ступенем їх небезпеки на три категорії. До категорії А зачислили найбільш небезпечні хвороби (чума, натуральна віспа, сибірка, гарячки Ебола й Марбург та інші), оскільки вони становлять найбільший ризик для біологічної безпеки країни. Ці хвороби схильні до швидкого поширення серед населення, спричиняючи високий рівень захворюваності та смертності, можуть призвести до масштабної паніки й потребують найбільших зусиль служби охорони здоров'я та профрільних науково-дослідних інститутів і лабораторій.

Категорію В складають менш небезпечні патогени, які розповсюджуються повільніше, ніж збудники першої групи. Вони спричиняють меншу захворюваність і смертність. Тому потребують менших зусиль з боку системи охорони здоров'я. До них належать інфекції, які пере- 


\section{ОГЛЯДИ ТА ЛЕКЦІї}

даються через продукти харчування та воду (наприклад, холера), і низка природно-осередкових інфекцій (комариний вірусний енцесраліт). До категорії С віднесено патогени, що спричиняють тяжкі хвороби, які в теперішніх умовах не здатні швидко розповсюдитися, але їх можна використати для біологічного тероризму.

Коли інфекційна захворюваність створює загрозу еволюційній перспективі людства, спільнота здійснює активні заходи щодо елімінації збудника, який її спричиняє. Протиепідемічні заходи можуть бути спрямовані на різні ланки епідемічного процесу, але в цілому вони проводяться комплексно, найбільш вдалим прикладом цього є натуральна віспа.

Заслуговує на увагу досвід подолання місцевої малярії в багатьох країнах, у тому числі й в Україні, після Другої світової війни. В наш час поки що вдається уникнути виникнення ії̈ природних осередків внаслідок завезених випадків [1, 2].

Американські фрахівці виділяють 3 категорії збудників особливо небезпечних інфрекцій, що можуть цікавити терористів як інструменти біологічної зброї, і відповідно визначають рівень готовності спецслужб і служб охорони здоров'я США до ліквідації наслідків актів біотероризму та вироблення заходів протидії. До вищої категорії інструментів біологічної зброї (категорія А) американські дослідники відносять збудників натуральної віспи, сибірки, чуми, ботулізму, туляремії, геморагічних гарячок. 3 цього списку лише 2-3 інфекційних агенти можуть бути реально використані групами терористів проти населення великих міст. Передусім це збудники натуральної віспи і сибірки, які особливо небезпечні в разі аерогенного зараження людей. У випадку використання одного або декількох інфекційних агентів на уражених територіях може скластися надзвичайно тяжка епідемічна ситуація, зумовлена низкою обставин.

У районах бойових дій та стихійних лих (землетрус, повінь, смерч, ураган тощо), при аваріях на підприємствах, які виробляють вакцини й інші бактерійні препарати, в місцях тимчасово розселення евакуйованого населення може виникнути складна санітарно-гігієнічна й епідемічна ситуація. Вона сприяє виникненню і поширенню серед населення інфекційних хвороб з розвитком епідемій. Під час стихійного лиха можуть активуватися природні осередки висококонтагіозних інфекцій (сибірка, чума, холера тощо). Так, за даними Державної служби надзвичайних станів, в Україні $є$ багато діючих природних осередків багатьох небезпечних інфекцій туляремії (у 23 областях), лептоспірозу (у всіх областях), сибірки (у 16 областях), гарячки Ку (у 9 областях), кліщового енцефраліту (у 8 областях), геморагічної гарячки з нирковим синдромом (у 10 областях), гарячки Західного Нілу (у 7 областях), Каліфорнійського енцефраліту (у
7 областях). Є епідеміологічні свідчення про необхідність вивчення нозоареалу псевдотуберкульозу, лістеріозу та інших природно-осередкових інфеекцій [3, 4].

Як свідчить практика, особливо небезпечною під час природних чи техногенних катастрофр може бути сибірка. У нашій країні є понад 10000 місць, ґрунти яких забруднені збудником цієї недуги. Вони становлять постійну загрозу захворювання, а при виникненні стихійних лих, зокрема повеней, паводків, можуть спричинити епідемічні спалахи або епізоотії.

Відомо, що з усіх об'єктів зовнішнього середовища в епізоотології особливе значення має ґрунт, який є головним структурним елементом будь-якого осередку захворювання. А тому, стаціонарно неблагополучні пункти, в яких знаходяться ґрунтові території (ділянки), контаміновані збудниками сибірки, є тією важливою епізоотичною структурою, яка в більшості визначає хід і розвиток епізоотичного процесу. Взагалі, ґрунт виступає в цьому ланцюгу не лише як резервуар збудника, але й як фрактор його передачі до сприйнятливих тварин і людей.

Отже, з однієї сторони, будь-які роботи, пов'язані із переміщенням великих мас землі (викорчовування невеликих перелісків, де колись відводились місця для захоронення трупів тварин, так звані скотомогильники, меліоративні, іригаційні роботи, будівництво нових шляхів, різних об'єктів) у неблагополучних пунктах без погодження $з$ відповідними службами, а з другої - природні фрактори - повені, розливи рік, намивання мулу, ерозії, вивітрювання ведуть до збільшення ризику виносу спор збудника хвороби на поверхню ґрунту, зараження ними кормів, води, а через останні - і сприйнятливих тварин.

Наприклад, влітку 1994 р. в с. Орани ВолодимирВолинського району Волинської області будувалася дорога. Переміщення ґрунту в окремих ділянках дороги, зокрема біля сільського кладовища, сягало по висоті 3-5 метрів. Зачеплений був і старий скотомогильник, що розташовувався неподалік. Внаслідок цього стався виніс спор збудника сибірки на поверхню ґрунту. Спекотливе літо із суховіями сприяло поширенню збудника хвороби на значну територію, уразивши передусім пасовище літнього табору великої рогатої худоби, що було поруч. Не забарилися спалахи сибірки серед телиць, які випасалися на пасовищі, незважаючи на те, що перед вигоном тварин у табір всі вони були щеплені проти сибірки вакциною, яка гарантує імунітет не менше, ніж на 6 міс. Очевидно, що тут стався винос величезної кількості спор збудника і зараження ними навколишніх кормових і сільськогосподарських угідь [1, 4].

Подібним до цього був випадок сибірки у корови взимку 1976 р. в колгоспі «Волинь» (с. Жашковичі Іва- 
ничівського району Волинської області). Стався він внаслідок завезення на територію вигульного майданчика фрерми збудника хвороби з торфом із урочища с. Переславичі, де більше 20 років тому до часу заготівлі торфу загинула від сибірки корова $[1,2]$.

Різноманітність біоценотичних зв'язків на території природних ландшастів України створює сприятливі умови для довготривалого існування природно-осередкових інфекцій, таких як туляремія, лептоспіроз, гарячка Ку, кліщовий вірусний енцеораліт, геморагічна гарячка 3 нирковим синдромом та інших.

Відомо, що на території Донецької та Луганської областей знаходяться природні осередки туляремії, джерелом якої $є$ гризуни. У зв'язку з подіями на сході держави, дератизаційні заходи на цій території проводяться у недостатньому обсязі або не проводяться взагалі. Під час епізоотичних обстежень реєструється

\section{Література}

1. Епідеміологічні аспекти біобезпеки : навчальний посібник / В.Л. Савицький, О.Д. Крушельницький, М.А. Андрейчин, І.В. Огороднійчук, О.М. Іванько. - Київ: «Видавництво Людмила», 2019. $-160 \mathrm{c}$.

2. Біологічна безпека України: монографія / за заг. ред. М.В. Величка, В.Г. Радченка. - Київ: Нац. акад. СБУ, 2016. - 784 с.

3. Тлумачення спеціальної термінології в системі заходів протиепідемічного захисту ЗС України / В.Л. Савицький, О.Д. Крушельницький, О.М. Іванько [та ін.]. - Київ: УВМА, 2018. - 68 с.

4. Епідеміологічне обстеження в осередках інсекційних хвороб в ЗС України в мирний та воєнний час / В.Л. Савицький, О.Д. Крушельницький, О.М. Іванько [та ін.]. - Київ: УВМА, 2019. - 56 с.

\section{BIOLOGICAL THREATS AND THEIR IMPACT ON THE EPIDEMIC SITUATION IN THE ARMED FORCES OF UKRAINE}

O.D. Krushelnytsky, I.V. Ohorodniychuk

Ukrainian Military Medical Academy, Kyiv

SUMMARY. The article considers the impact of biological threats on the epidemiological situation, summarizes велика кількість гризунів. При польовому розміщенні військ це загрожує виникненню та розповсюдженню захворювань серед військовослужбовців [2, 4].

\section{Висновок}

Порушення фрункції взаємного обміну інформацією щодо випадків особливо небезпечних інорекційних захворювань у питаннях виникнення або активації осередків природно-осередкових інфекційних захворювань, у зв'язку із скороченням державної санітарно-епідеміологічної служби та відсутністю на даний час дієвого епідемічного моніторингу за захворюваністю серед цивільного населення, негативно впливає на загальний рівень безпеки у державі в цілому та може вплинути на стан боєздатності воєнних підрозділів, що перебувають у польових умовах в зоні проведення операції об'єднаних сил.

\section{References}

1. Savytskyy, V.L., Krushelnytskyy, O.D., Andreychyn, M.A., Ohorodniychuk, I.V., \& Ivanko, O.M. (2019). Epidemiological aspects of biosafety. Kyiv: Ludmila Publishing House [in Ukrainian].

2. Welychko, M.V., \& Radchenko, R.H. (2016). Biological safety of Ukraine: monograph. Kyiv: National acad. SSU [in Ukrainian].

3. Savytskyy, V.L., Krushelnytskyy, O.D., Ivanko, O.M., Ohorodniychuk, I.V., \& Omelyashko, M.I. (2018). Interpretation of special terminology in the system of anti-epidemic protection measures of the Armed Forces of Ukraine. Kyiv: UVMA [in Ukrainian].

4. Savytskyy, V.L., Krushelnytskyy, O.D., Ivanko, O.M., Zhaldak, N.Yu., Bezkorovaynyy V.Yu., \& Ohorodniychuk, I.V., (2019). Epidemiological examination in the centers of infectious diseases in the Armed Forces of Ukraine in peacetime and wartime. Kyiv: UVMA [in Ukrainian]. the considerations for risk management of infectious diseases, focuses on emergent and re-emergent infections and bioterrorism.

Key words: biological threats; epidemic situation; ecological safety; biological agents. 


\section{Відомості про авторів:}

Крушельницький Олександр Данилович - к. мед. н., доцент, доцент кафедри військово-профрілактичної медицини Української військово-медичної академії (м. Київ); e-mail: iro4ka.ogo@ukr.net

Огороднійчук Ірина Володимирівна - д. мед. н., доцент, професор кафедри військово-профрілактичної медицини Української військово-медичної академії (м. Київ); e-mail: iro4ka.ogo@ukr.net

\section{Information about the authors:}

Krushelnytskyy O. D. - PhD, Associate Professor of the Department of Military Preventive Medicine, Ukrainian Military Medical Academy (Kyiv); e-mail: iro4ka.ogo@ukr.net

Ohorodniychuk I. V. - MD, Associate Professor, Professor of the Department of Military Preventive Medicine, Ukrainian Military Medical Academy (Kyiv); e-mail: iro4ka. ogo@ukr.net

Конорлікту інтересів немає.

The authors have no conflicts of interest to declare.

Отримано 12.11.2020 p.

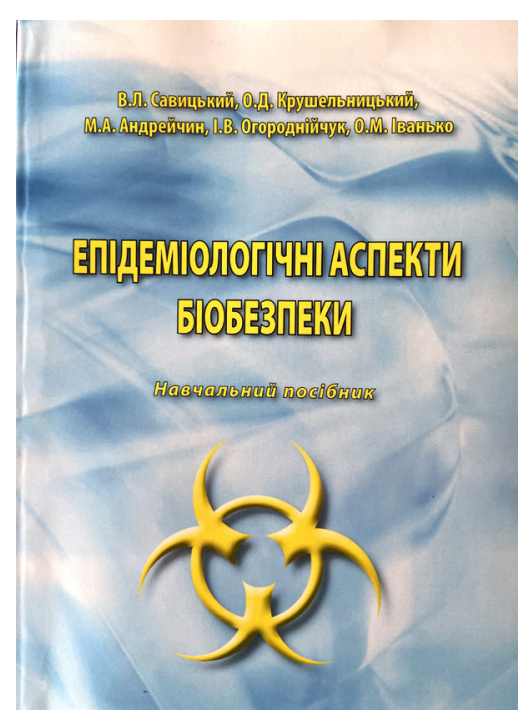

Посібник відповідає навчальній програмі з дисципліни «Епідеміологічні аспекти біобезпеки» і призначений для слухачів Української військово-медичної академії IV рівня акредитації, лікарів-епідеміологів, ад'юнктів, науковців, викладачів МО України, а також інших силових міністерств та відомств.

\section{ВИЙШОВ НОВИЙ НАВЧАЛЬНИЙ ПОСІБНИК!}

Епідеміологічні аспекти біобезпеки : навчальний посібник / В.Л. Савицький, О.Д. Крушельницький, М.А. Андрейчин, І.В. Огороднійчук, О.М. Іванько. - Київ : Видавництво «Людмила», 2019. - 160 с.

У навчальному посібнику висвітлюються сучасні вимоги до біологічної безпеки та біозахисту. Окремі розділи присвячені впливу епідемічної складової на стан біологічного захисту, також розглядаються питання біологічної зброї та біотероризму і заходи суворого протиепідемічного режиму. 